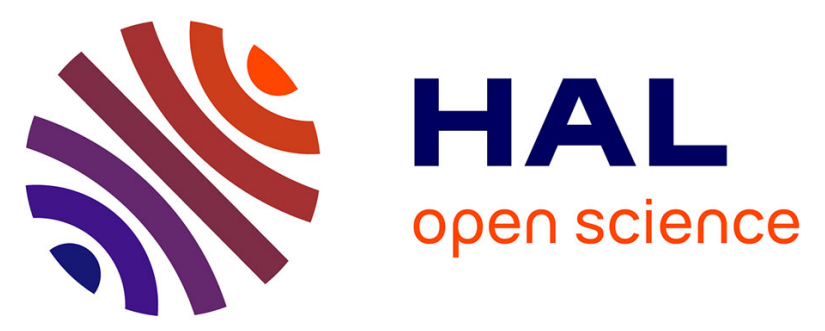

\title{
Rosiglitazone induces interleukin-1 receptor antagonist in interleukin-1beta-stimulated rat synovial fibroblasts via a peroxisome proliferator-activated receptor beta/delta-dependent mechanism
}

David Moulin, Arnaud Bianchi, Sandrine Boyault, Sylvie Sébillaud, Meriem Koufany, Mathias Francois, Patrick Netter, Jean-Yves Jouzeau, Bernard Terlain

\section{- To cite this version:}

David Moulin, Arnaud Bianchi, Sandrine Boyault, Sylvie Sébillaud, Meriem Koufany, et al.. Rosiglitazone induces interleukin-1 receptor antagonist in interleukin-1beta-stimulated rat synovial fibroblasts via a peroxisome proliferator-activated receptor beta/delta-dependent mechanism. Arthritis and Rheumatism, 2005, 52 (3), pp.759-769. 10.1002/art.20868 . hal-01715364

\author{
HAL Id: hal-01715364 \\ https://hal.science/hal-01715364
}

Submitted on 22 Feb 2018

HAL is a multi-disciplinary open access archive for the deposit and dissemination of scientific research documents, whether they are published or not. The documents may come from teaching and research institutions in France or abroad, or from public or private research centers.
L'archive ouverte pluridisciplinaire HAL, est destinée au dépôt et à la diffusion de documents scientifiques de niveau recherche, publiés ou non, émanant des établissements d'enseignement et de recherche français ou étrangers, des laboratoires publics ou privés. 


\title{
Rosiglitazone Induces Interleukin-1 Receptor Antagonist in Interleukin-1 -Stimulated Rat Synovial Fibroblasts via a Peroxisome Proliferator-Activated Receptor / -Dependent Mechanism
}

\author{
David Moulin, ${ }^{1}$ Arnaud Bianchi, ${ }^{1}$ Sandrine Boyault, ${ }^{1}$ Sylvie Sebillaud, ${ }^{1}$ Meriem Koufany, ${ }^{1}$ \\ Mathias Francois, ${ }^{2}$ Patrick Netter, ${ }^{1}$ Jean-Yves Jouzeau, ${ }^{1}$ and Bernard Terlain ${ }^{1}$
}

Objective. To study the potency of 2 peroxisome proliferator-activated receptor (PPAR) agonists, 15-deoxy- 12,14-prostaglandin $\mathrm{J}_{2}\left(15\right.$-deoxy-PGJ $\left.\mathrm{J}_{2}\right)$ and rosiglitazone, to modulate the expression of interleukin-1 receptor antagonist (IL-1Ra) in rat syno- vial fibroblasts.

Methods. Levels of messenger RNA for IL-1Ra and PPAR isotypes (, /, ) were assessed by real- time polymerase chain reaction in rat synovial fibro- blasts exposed to $10 \mathrm{ng} / \mathrm{ml}$ of IL-1. PPAR levels were assessed by Western blotting and secreted IL-1Ra levels by immunoassay. The potency of PPAR agonists and the PPAR / agonist GW-501516 on IL-1Ra levels was tested in the range of 1-10 $M$ and at $100 \mathrm{p} M$, respec- tively. The contribution of PPAR to the effects of rosiglitazone on IL-1Ra secretion was examined either by its overexpression or by inhibition using wild-type or dominant-negative constructs and the antagonist GW-

$9662(10 M)$, respectively. The dominant-negative

strategy was also performed to investigate the possible contribution of PPAR / and NF- B activation.

Results. IL-1 -induced IL-1Ra production was increased by $10 M$ rosiglitazone but was reduced dosedependently by 15-deoxy-PGJ ${ }_{2}$. Both agonists low- ered IL-1 secretion, but rosiglitazone alone reduced the imbalance of IL-1 /IL-1Ra toward basal levels. Enhancement of IL-1 -induced IL-1Ra production by rosiglitazone was not affected by PPAR overexpression or by its inhibition with dominant-negative PPAR or GW9662. Inhibition of NF- B was also ineffective against rosiglitazone but abolished the stimulating ef-fect of IL-1 on IL-1Ra. All PPAR isotypes were ex- pressed constitutively in rat synoviocytes, but PPAR decreased dramatically upon IL-1 exposure, whereas PPAR / remained stable. Dominant-negative PPAR / abolished the enhancement of IL-1Ra by rosiglitazone, whereas GW-501516 reproduced the effect of rosiglitazone on IL-1Ra secretion.

Conclusion. Rosiglitazone stimulates IL-1Ra pro- duction by a PPAR / mechanism in activated rat synovial fibroblasts, further contributing to its potential antiarthritic properties and opening new perspectives for the modulation of inflammatory genes by specific PPAR agonists in articular cells.

Rheumatoid arthritis (RA) is a chronic inflam- matory disease characterized by persistent synovitis, with synovial hypertrophy secondary to dysregulated proliferation of synovial cells, and infiltration by peri-

pheral blood mononuclear cells. Resident as well as infiltrating cells produce numerous inflammatory cyto- kines,

including tumor necrosis factor (TNF) and interleukin 1 (IL-1), which play a central role in the pathogenesis of RA (14). Thus, agents that reduce the production and/or activity of IL-1 and TNF are now used in rheumatology practices for the treatment of severe inflammatory diseases (5-7).

The production and biologic activity of IL-1 are highly regulated events (8), ranging from the control of IL-1 gene expression, protein synthesis, and processing by IL-1 - converting enzyme (caspase 1) to the variable expression of cell surface receptors and their soluble counterparts or the neutralization of the effects of IL-1 by a natural receptor antagonist (IL-1Ra). The IL-1 receptor family is composed of 2 receptors that have different physiologic roles: the type 1 receptor (IL-1RI), which transduces a signal upon IL-1 binding, and the type 2 receptor (IL-1RII), which fails to transduce signal and has been called a "decoy" receptor (8). When IL-1 binds to IL-1RI, a complex is formed, which then binds to the IL-1R accessory protein, which is essential to IL-1 signaling through the formation of a high-affinity bind- ing complex (9). Indeed, IL-1RI is incapable of signal transduction on its own (10), whereas the high-affinity complex further recruits the adaptor protein MyD88 and the IL-1R-associated kinase to generate intracellular events through signaling pathways that are not restricted to IL-1. Modulating IL-1 at the presignaling level, for example, by interfering with its binding on specific membrane receptors, is therefore a promising approach that has high therapeutic relevance (6).

IL-1Ra, a member of the IL-1 gene family, is the first natural antagonist identified in cytokine receptor studies that inhibits the effects of IL-1 on target cells because of its inability to recruit IL-1R accessory protein upon binding to IL-1RI 
(11). As a consequence, IL-1Ra can have both systemic and cellular effects by inhibiting IL-1 and IL-1. Furthermore, IL-1Ra binds to IL-1RII with an affinity that is 100-500 times lower than its affinity to bind to IL-1RI, thus contributing to the reduction of IL-1 signal transduction (12). Despite the close affinity of IL-1 and IL-1Ra for IL-1RI, an excess of IL$1 \mathrm{Ra}$ is required to inhibit IL-1 activity (8), and the imbalance between IL-1Ra and IL-1 may predispose to the perpetuation of inflammation in human (13) and experimental (14) arthritis. Indeed, both systemic infu- sion of large amounts of IL-1Ra (11) and local overex- pression of IL-1Ra by gene transfer (15) reduced the severity of experimental arthritis and the progression of experimental osteoarthritis, respectively. Similarly, mice deficient in the IL-1Ra gene were shown to spontane- ously develop a chronic inflammatory arthropathy that resembled RA (16), further highlighting the pivotal role of IL-1Ra in counterbalancing the activity of IL-1 in the body.

Peroxisome proliferator-activated receptors (PPARs; isotypes , /, ) are ligand-inducible nuclear transacting factors (17). PPAR heterodimerizes with reti- noid X receptor (18) and binds to peroxisome proliferator- activated receptor response element (PPRE) located in the promoter region of PPAR target genes. These lipid- sensitive receptors can be activated in a variable isotype- specific manner by natural fatty acids, leukotrienes, pros- taglandins, and some synthetic agonists, including the antidiabetic drugs (thiazolidinediones [TZDs]), which have recently emerged as modulators of inflammation $(17,19,20)$. Indeed, several recent studies have shown that activation of PPAR , either by endogenous ligands, such as

15-deoxy- ${ }^{12,14}$-prostaglandin $\mathrm{J}_{2}$ (15-deoxy-PGJ ${ }_{2}$ ), or by

TZD had antiinflammatory potencies in rodent models of

arthritis (21-24). At the cellular level, 15-deoxy-PGJ ${ }_{2}$ and TZD were shown to inhibit the transcriptional induction of genes thought to contribute to joint pathology, such as TNF (19,20), IL-1 (20), gelatinase B (19), inducible nitric oxide synthase, and matrix metalloproteinase 13 (25). PPAR / is the less well-characterized PPAR isotype, despite its ubiquitous expression. It appears to take part in reverse transport of cholesterol, wound healing, cell proliferation, and apoptosis, although its contribution to inflammation remains largely unknown (26). A highly selective PPAR / agonist has been synthesized only very recently (27).

We previously demonstrated that PPARs and were expressed constitutively in rat synovial fibroblasts and that PPAR agonists inhibited TNF and IL-1 gene expression through interaction with the NF- B signaling pathway (28). However, we hypothesized that the antiarthritic potency of PPAR ligands could also be supported by their ability to interfere with cytokine presignaling, either by increasing receptor shedding or, in the case of IL-1, by the synthesis of its natural antagonist. Consistent with our hypothesis, a recent study showed that TZD enhanced IL-1Ra secretion in monocytic cells stimulated with phorbol myristate ace- tate (PMA) (29), further suggesting that PPAR ago- nists could contribute to cytokine neutralization in ad- dition to inhibiting their expression.

Therefore, we studied the ability of 2 PPAR

agonists, the natural low binding-affinity compound

15-deoxy-PGJ ${ }_{2}$ and the synthetic high binding-affinity TZD rosiglitazone, to modulate IL-1Ra in rat synovial fibroblasts stimulated with homologous IL-1. This cell type was shown to be unable to produce enough IL-1Ra to counteract IL-1 during the course of RA $(13,30)$ and to be highly responsive to IL-1, which plays a key pathophysiologic role in arthritis (1). Under these experimental conditions, we showed an opposite effect of PPAR agonists on the expression and secretion of IL-1Ra as well as on the balance between IL-1 and IL-1Ra. We also explored the mechanisms supporting the induction of IL-1Ra by rosiglitazone. Overexpres- sion of wild-type or dominant-negative forms of PPAR , as well as the use of a specific PPAR antagonist, failed to modify the impact of rosiglitazone on IL-1Ra secre- tion. Rosiglitazone-induced IL-1Ra secretion was unaf- fected by transfection with a dominant-negative vector of NF- B, whereas it was suppressed in the presence of a dominant-negative vector of PPAR / A PPAR / - dependent induction of IL-1Ra secretion by rosiglita- zone was further supported by the stimulating effect of the PPAR / agonist GW-501516 and the high and invariable expression of PPAR / in IL-1 -stimulated cells.

\section{MATERIALS AND METHODS}

Isolation and culture of synovial fibroblasts. Synovial tissues were obtained surgically from the knee joints of male Wistar rats weighing 130-150 gm (Charles River, L'Arbresle, France) that had been killed under anesthesia. Synovial fibro- blasts were obtained by sequential digestion with Pronase and collagenase B (Roche Molecular Biochemicals, Meylan, France) as described previously (28). The cells were washed 2 times in phosphate buffered saline (PBS) and cultured to confluence in $75-\mathrm{cm}^{2}$ flasks at $37^{\circ} \mathrm{C}$ in a humidified atmosphere containing 5\% $\mathrm{CO}_{2}$. The medium used was Dulbecco's modi- fied Eagle's medium-Ham's F12 supplemented with Lglutamine $(2 \mathrm{mM})$, penicillin $(100$ units $/ \mathrm{ml})$, streptomycin $(100 \mathrm{~g} / \mathrm{ml})$, amphotericin $\mathrm{B}(50 \mathrm{ng} / \mathrm{ml})$, and $10 \%$ heat- inactivated fetal calf serum (FCS) (Invitrogen, Cergy-Pontoise, France). Synovial cells were subcultured under similar condi- tions and were used between passages 3 and 6 , which corre- 
RNA extraction and real-time polymerase chain reac- tion (PCR) analysis. Total RNA from cultured synoviocytes was isolated using TRIzol (Invitrogen). Two micrograms of total RNA was reverse-transcribed for 90 minutes at $37^{\circ} \mathrm{C}$ using hexamer random primers and 200 units of Moloney murine leukemia virus reverse transcriptase (Invitrogen). To quantify IL-1Ra, PPAR, PPAR / and PPAR mRNA ex-pression, a real-time quantitative PCR was performed using LightCycler (Roche Molecular Biochemicals) technology.

Primer sequences and annealing temperatures were as follows: for IL-1Ra, 5 -GACCTTCTACCTGAGGAACAA- CCA-3 (forward) and 5 -AAGAACACATTCCGAAAGT- CAATAGG-3 (reverse) at $62^{\circ} \mathrm{C}$; for PPAR , 5 -ACTATGGAGTCCACGCATGTGA-3 (forward) and 5 -TTGT- GGTACGCCAGCTTTAGC-3 (reverse) at 55 ${ }^{\circ} \mathrm{C}$; for PPAR /,

5 -CCAGCAGCTGCACAGACCTCTC-3 (forward) and 5 - ATCTGCAGCTGGTCCAGCA-3 (reverse) at 58 ${ }^{\circ}$; for PPAR, 5 GCTGGTCGATATCACTGGAGATC-3 (forward) and 5 -CACAATGCCATCAGGTTTGG-3 (reverse) at 55 ${ }^{\circ} \mathrm{C}$; and for $\mathrm{S} 29$, 5 AGATGGGTCACCAGCAGCTCTACTG-3 (forward) and 5 -AGACGCGGCAAGAGCGAGAA-3 (re- verse) at $59^{\circ} \mathrm{C}$.

PCR was performed with the SYBR Green Master Mix system (Qiagen, Courtaboeuf, France). Melting curve analysis was performed after amplification to determine the melting temperature of the specific PCR products, and product sizes were examined on a $2 \%$ agarose gel stained with ethidium bromide $(0.5 \mathrm{~g} / \mathrm{ml})$. Each run included standard dilutions and positive and negative reaction controls. The mRNA level of the gene of interest and of the ribosomal protein S29, which was chosen as the housekeeping gene, were determined in parallel for each sample. Results were expressed as the normalized ratio of the mRNA level of each gene of interest to that of the S29 gene.

Transient transfection experiments. Synovial fibro- blasts were seeded in 6-well plates at 5 10 cells/well and grown to $80 \%$ confluence. Cells were transfected with either

500 ng of a PPAR expression vector (pcDNA3.1 PPAR; a generous gift from Dr. H. Fahmi, Centre Hospitalier de l'Universit'e de Montr'eal, Montreal, Quebec, Canada), 500 ng of a dominant-negative vector of PPAR (PPAR mutated in ments, cells were grown and maintained in $1 \%$ FCS (low FCS)

culture medium.

Study design. Synoviocytes were cultured in low FCS

culture medium in the presence or absence (vehicle alone,

$0.1 \%$ of DMSO final concentration) of PPAR ligands, which were added at the same time as $10 \mathrm{ng} / \mathrm{ml}$ of interleukin-1 (Sigma, St. Quentin Fallavier, France). The level of messenger RNA (mRNA) for IL-1Ra was determined 12 hours after IL-1 challenge, whereas the level of secreted IL-1Ra was assayed in supernatants at 24 hours. Expression of PPAR isotypes was studied on synoviocytes stimulated with $10 \mathrm{ng} / \mathrm{ml}$ of IL-1 for 6 hours (mRNA analysis) or for 12 hours (protein analysis). The PPAR ligands used were rosiglitazone $(1,3$, or

10 M; Cayman Chemical, Ann Arbor, MI), 15-deoxy-PGJ $(1$, 3, or $10 M$; Calbiochem, Meudon, France), the PPAR antagonist GW-9662 (10 M; Cayman Chemical), and the PPAR / agonist GW-501516 (100 pM; Alexis Biochemicals, Paris, France).

by Gurnell et al [32]; a generous gift from Dr. M. T. Corvol,

Unit'e Mixte de Recherche INSERM 530, Universit'e Paris V, Paris, France), 500 ng of a dominant-negative vector of PPAR / (PPAR / mutated in the loop preceding the AF-2 domain [Glu $\left.{ }^{411} \mathrm{Pro}\right]$ as described by Grimaldi et al [33]; a generous gift from Dr. P. A. Grimaldi, INSERM U470, Universit'e de Nice-Sophia Antipolis, Nice, France), 500 ng of a dominant-negative vector of NF$\mathrm{B}$ (I B mutated $\left[\mathrm{Ala}^{32}, \mathrm{Ala}^{36}\right.$ ]; Clontech, Palo Alto, CA), or $1 \mathrm{~g}$ of PPRE-Luc and 1

$\mathrm{g}$ of NF- B-Luc (a generous gift from Dr. H. Fahmi) for gene reporter assays.

Transfections were performed for 2 hours using 101 of polyethyleneimine reagent (Euromedex, Souffelweyer-sheim, France) in $1 \mathrm{ml}$ of complete medium. Twenty-four hours after transfection, cells were stimulated with IL-1 for 24 hours in the presence or absence of PPAR agonists.Gene reporter activity. After transient transfection with plasmid reporter as described above, cells were harvested in Cell-Culture Lysis Reagent (Promega, Charbonni`eres, France) before measurement of luciferase activity according to the recommendations of the manufacturer (Promega). Western blot analysis of PPAR isotypes. Cells exposed to IL-1 were washed twice with ice-cold PBS and scraped off the flask in cold lysis buffer $(20 \mathrm{~m} M$ Tris pH 7.5, $150 \mathrm{~m} M \mathrm{NaCl}, 1 \mathrm{~m} M$ EDTA, $1 \mathrm{~m} M$ EGTA, $1 \%$ Triton X-100, $2.5 \mathrm{~m} M$ sodium pyrophosphate, $1 \mathrm{~m} M$-glycerophosphate, $1 \mathrm{~m} M \mathrm{Na}_{3} \mathrm{VO}_{4}, 1 \mathrm{mg} / \mathrm{ml}$ of leupeptin, and $1 \mathrm{~m} M$ phenylmethyl- sulfonyl fluoride). Cells were disrupted by sonication and centrifuged at 3,000 revolutions per minute for 10 minutes. The supernatants were collected, and the protein concentra- tion was determined by an assay based on the method of Bradford.Protein samples $(25 \mathrm{~g})$ were analyzed by sodium dodecyl sulfate-polyacrylamide gel electrophoresis (10\% acrylamide) and electroblotted onto polyvinylidene difluoride membrane. After 1 hour in blocking buffer (Amersham Bio- sciences, Orsay, France), membranes (Immobilon; Waters, St. Quentin-en-Yvelines, France) were blotted overnight at $4^{\circ} \mathrm{C}$ with antibodies against PPAR (Tebu, Le Perray-en- Yvelines, France), against PPAR / or PPAR (generous giftsfrom Professor Michel Dau,ca, Universit eHenri Poincar'e,Vandoeuvre-les-Nancy, France), and against -actin (Sigma); all antibody dilutions were 1:1,000. After 3 washings with Tris buffered saline (TBS)-Tween, the blot was incubated with anti-rabbit IgG conjugated with horseradish peroxidase (Cell Signaling, Beverly, MA) at a dilution of 1:2,000 in blocking buffer for 1 hour at room temperature. After 4 washings with TBS-Tween, protein bands were detected by chemilumines- cence with the Phototope Detection system according to the manufacturer's instructions (Cell Signaling).

Quantitative determination of IL-1Ra and IL-1 in cell culture medium. Levels of IL-1Ra and IL-1 were measured in culture supernatants according to the manufac- turer's instructions (BioSource International, Camarillo, CA, and R\&D Systems, Minneapolis, MN, respectively), using solid-phase sandwich enzyme-linked immunosorbent assays (ELISAs). Absorbance was read at $450 \mathrm{~nm}$ on a microplate reader (Multiscan; Labsystems, Montigny-le-Bretonneux, France). The limits of detection were $12 \mathrm{pg} / \mathrm{ml}$ for IL-1Ra and

$5 \mathrm{pg} / \mathrm{ml}$ for IL-1. The assays showed no cross-reactivity between rat IL-1, IL-1, and IL-1Ra (manufacturers' data). Positive controls provided by the manufacturers were used in each experiment.

Statistical analysis. Results are expressed as the mean SD of at least 3 assays. Comparisons were made by analysis of variance, followed by Fisher's protected least sig-nificant difference post hoc test using StatView version 5.0 software (SAS Institute, Cary, NC). $P$ values less than 0.05 were considered significant. 
Effects of PPAR agonists on IL-1Ra expression in IL-1 -stimulated synoviocytes. Preliminary experi- ments using an MTT assay showed no modification of cell viability and proliferation in rat synovial fibroblasts treated with IL-1 (10 $\mathrm{ng} / \mathrm{ml}$ ) and/or PPAR agonists in the concentration range tested. Under the experimental conditions we used, untreated cells showed a basal level of mRNA for IL-1Ra that was unaffected by rosiglita- zone $(10 M)$ but was reduced by 15-deoxy$\mathrm{PGJ}_{2}$ at the same concentration (Figure 1A). Similar effects on basal secretion of IL-1Ra were observed (Figure 1B).

Stimulation with IL-1 induced IL-1Ra mRNA expression; this effect was decreased by 15 -deoxy-PGJ ${ }_{2}$, but slightly increased by rosiglitazone (Figure 1A). Ros- iglitazone also increased (2.5-fold) the stimulating effect of IL-1 on IL-1Ra secretion, while 15-deoxy-PGJ ${ }_{2}$ suppressed the IL-1Ra level below the control level in IL-1 -stimulated cells (Figure 1B). Previous dose- ranging experiments showed that rosiglitazone stimu- lated IL-1 -induced IL-1Ra secretion only at the high- est concentration used $\left(\begin{array}{ll}10 & M\end{array}\right)$, whereas 15 -deoxy-PGJ ${ }_{2}$ had a close dose-related inhibitory effect, and that other agonists of PPAR isotypes (troglitazone at 1,3, or $10 u M$ ) and (Wy-14,643 at 1, 10, or $100 \mathrm{u} M$ ) had no effect on this parameter (data not shown).

Effects of PPAR agonists on IL-1 production. To investigate effects of PPAR ligands on IL-1 secre- tion, experimental conditions were adapted as follows: after 12 hours of stimulation with exogenous rat IL-1, culture medium was replaced by fresh medium without IL-1 to check for endogenous IL-1 production in the culture supernatant. No spontaneous secretion of IL-1 was detected under these conditions, but IL-1 chal- lenge increased both IL-1Ra and IL-1 levels (Table 1), although to a different extent. Indeed, IL-1Ra secretion was increased 7-fold, whereas IL-1 secretion was increased at least 47 -fold, leading to an increased ratio of IL-1 to IL-1Ra as compared with basal conditions. PPAR agonists failed to affect IL-1 secretion in resting cells, whereas again, 15-deoxy-PGJ ${ }_{2}$ reduced the

basal secretion of IL-1Ra (Table 1). In IL-1 -stimulated

cells, rosiglitazone and 15-deoxy-PGJ ${ }_{2}$ reduced IL-1 secretion to a similar extent, but confirmed their oppo- site effects on IL-1Ra secretion, with slight stimulation by rosiglitazone and strong inhibition by 15 -deoxy-PGJ ${ }_{2}$ (Table 1). As a consequence, rosiglitazone lowered the ratio of IL-1 to IL-1Ra toward basal values, whereas

15-deoxy-PGJ $\mathrm{J}_{2}$ aggravated the imbalancing effect of

IL-1 on this ratio.

Effects of PPAR modulation on rosiglitazone- induced IL-1Ra secretion. In the presence of the specific PPAR antagonist GW-9662 (10 M), the stimulatingeffect of rosiglitazone on IL-1 -induced IL-1Ra secre- tion was not appreciably changed (Figure 2A). Overex- pression of PPAR was ineffective in modulating both basal and IL-1 -stimulated IL-1Ra secretion as com- pared with cells transfected by an empty vector (Figure

2B). In cells overexpressing PPAR, the stimulating effect of rosiglitazone on IL-1Ra secretion was similar to that in controls (Figure 2B). In synoviocytes transfected with a dominant-negative form of PPAR 24 hours before IL-1 exposure, the stimulating effect of rosigli- tazone on IL-1Ra secretion was not appreciably modi- fied (Figure 2B).

Control experiments showed that PPRE-Luc ac- tivity was enhanced by rosiglitazone in PPAR - overexpressing cells, thus demonstrating that overex-pression was effective. As shown in Figure 2C, inhibition of PPAR by either the specific antagonist GW-9662 (10

$M$ ) or the dominant-negative form of PPAR were both effective in our model. Under these experimental conditions, the ability of rosiglitazone to decrease IL-

1 -induced nitrite levels in culture supernatants was significantly reduced by transfection with the dominant- negative form of PPAR while being triggered by trans- fection with its wild-type form (data not shown).

Effects of NF- B inhibition on rosiglitazone- induced IL-1Ra secretion. In synoviocytes transfected with a dominant-negative form of NF- B 24 hours before IL-1 challenge, the stimulating effect of IL-1 on IL-1Ra secretion was abolished (Figure 3A). How ever, the potentiating effect of rosiglitazone on the IL-1Ra level was essentially unaffected by inhibition of NF- B activation (Figure 3A). Control experiments confirmed that dominant-negative NF- B was able to reverse the modulation of NF- B activation by IL-1 in synoviocytes transfected with NF- B-Luc (Figure 3B).

Pattern of expression of PPAR isotypes in IL-1 - stimulated synoviocytes. Real-time PCR (Figure 4A) and Western blot (Figure 4B) analyses of PPARs demonstrated that all isotypes were constitutively ex-pressed in rat synovial fibroblasts. In IL-1 -stimulated cells, PPAR / and PPAR expression remained essen- tially unchanged, whereas PPAR decreased dramati- cally, both at the mRNA and protein levels (Figures 4Aand B)

Contribution of PPAR / to rosiglitazone- induced IL-1Ra secretion. In synoviocytes transfected with a dominantnegative form of PPAR /, the stimu- lating effect of rosiglitazone was abolished, which is contrary to the results of control experiments with a dominant-negative form of PPAR (Figure 5A). In both cases, the effect of IL-1 on IL-1Ra secretion was maintained. The PPAR / agonist GW-501516 (100 pM) reproduced the stimulating effect of rosiglitazone on IL-1Ra secretion in IL-1 -stimulated cells, without modifying its basal level

\section{DISCUSSION}

Several recent studies have highlighted the anti- inflammatory properties of PPAR agonists, either 15- deoxy-PGJ $\mathrm{J}_{2}$ or TZD, in experimental models of acute digestive (23) or periarticular (22) inflammation, as well as chronic polyarthritis 
$(21,24)$. Interestingly, it was recently demonstrated in the carrageenan-induced pleu- risy model that rosiglitazone reduced pleural exudate volume and mononuclear cell infiltration (22), as was previously shown for 15-deoxy-PGJ $\mathrm{J}_{2}$ (34), which was therefore proposed to promote the resolution of inflam- mation (35). Within joints, several types of cells could support the antiinflammatory potency of PPAR agonists, since this PPAR isotype is expressed constitutively in synovio- cytes (24), macrophages (19), and chondrocytes (36). In addition, each cell type has pathophysiologic relevance to joint inflammation by their production of mediators of inflammation or matrix-degrading enzymes and can therefore be considered a pharmacologic target for PPAR agonists (37). Consistent with this idea, PPAR ligands have been shown to decrease the expression of TNF in activated synoviocytes (28) and macrophages (19) and the production of various matrix metallopro- teinases in chondrocytes $(25,38)$ and synoviocytes $(39)$. Synoviocytes may play a crucial role because of their ability to proliferate under inflammatory conditions (40) and to cooperate with both macrophages in the synovial pannus and chondrocytes at the synovium-cartilage junction (41). In addition, the increased expression of proinflammatory cytokines within the rheumatoid syno- vium (42) is accompanied by an imbalance between IL-1 and its natural antagonist IL-1Ra in synoviocytes (13), further explaining the major contribution of IL-1 to cartilage destruction. This led us to study the potency of PPAR agonists to restore the balance between IL-1 and IL-1Ra in synovial fibroblasts.

In the present study, we confirmed that synovio- cytes stimulated with IL-1 produced increased amounts of IL-1Ra $(43,44)$, as has also been reported for mono- nuclear phagocytes (45) and articular chondrocytes (44). However, this potent negative-feedback loop was not sufficient by itself to counterregulate the effects of IL-1, since IL-1 also stimulated the production of IL-1 and to a greater extent, as illustrated by the increased ratio of IL-1 to IL-1Ra in stimulated cells. Thus, our experi- mental model reproduces part of the well-described cytokine imbalance reported in RA (13) and other inflammatory situations (46).

Under the conditions used in the present study, the synthetic PPAR agonist rosiglitazone and the nat- ural PPAR agonist 15-deoxy-PGJ ${ }_{2}$ showed opposite effects on IL-1Ra secretion, although both agonists

reduced nitric oxide production. Such differences be- tween natural and synthetic PPAR ligands is not sur- prising, since it has been reported in other cell types, including chondrocytes (47-49). In synoviocytes, rosigli- tazone partly restored the imbalance between IL-1 and IL-1Ra, whereas 15-deoxy-PGJ ${ }_{2}$ triggered the deleteri- ous effects of IL-1 because of its ability to decrease the production of IL-1Ra more efficiently than that of IL-1. This result is in contrast with the work of Meier et al (29), who demonstrated that in THP-1 cells stimu lated with PMA, both rosiglitazone and 15-deoxy$\mathrm{PGJ}_{2}$

stimulated the production of IL-1Ra, whereas only

15-deoxy-PGJ ${ }_{2}$ reduced the production of IL-1. Such a discrepancy could be ascribed to differences in cell types (monocytic versus mesenchymal), differences in the na- ture of the inflammatory stimulus (cytokine versus tu-mor inducer), or both, since biologic responses to PPAR agonists are thought to be largely cell-specific (20).

In synoviocytes, 15-deoxy-PGJ ${ }_{2}$ and rosiglitazone are also distinguished by their ability to affect IL-1Ra production in resting or activated cells. Indeed, we found that 15-deoxy-PGJ $\mathbf{J}_{2}$ was active independently of cell stimulation, whereas rosiglitazone required chal- lenge with IL-1 in order to be effective. This result confirmed that the induction of IL-1Ra secretion by rosiglitazone depended upon prior cell stress (29), al- though it may be supported by the modulation of IL-1-specific signaling pathways. Finally, the inhibitory effect of 15-deoxy-PGJ ${ }_{2}$ on IL-1Ra secretion (Figure

1B) paralleled its inhibitory potency on IL-1Ra mRNA (Figure 1A), whereas rosiglitazone was essentially active with regard to IL-1Ra production. Although not sup- ported by previous studies on the stabilization of mRNA by PPAR activators $(50,51)$, some posttranscriptional/ translational regulation of IL-1Ra by rosiglitazone can- not be excluded, since it was recently shown to contrib- ute to the control of human immunodeficiency virus type

1 replication by PPAR agonists (52). This result con-firms the apparent discrepancy between the reported levels of mRNA and protein in inflamed synovium for at least $2 \mathrm{IL}-1 \mathrm{Ra}$ isoforms (14).

Modulation of the function of PPAR was per-formed to investigate whether the effects of rosiglita-zone on IL-1 -induced IL-1Ra secretion was attribut- able to activation of this isotype. Overexpression of either the functional or dominant-negative forms of PPAR, as well as use of the specific antagonist GW-

9662, did not alter the potency of rosiglitazone to stimulate IL-1Ra secretion. Although not investigated in the present study, PPAR -independent effects have been reported largely for 15-deoxy-PGJ ${ }_{2}$, with direct

links to inhibition of NF- B transactivation (53) or

modulation of oxidative stress (54). However, rosiglita- zone is one ligand that has a high affinity for PPAR (55), which was shown to modulate PPAR -dependent genes in experimental diabetes (56) and atherosclerosis (57). Therefore, we hypothesized that rosiglitazone would modulate alternate molecular targets when used at the (micromolar) concentration necessary to enhance IL-1Ra secretion.

To examine this hypothesis, we first checked for

the possible modulation of the NF- B pathway. As has been reported in studies of IL-1-stimulated synoviocytes (58) and PMA-stimulated THP-1 cells (59), we demon- strated that activation of the NF- B pathway contrib- uted to the stimulating effect of IL-1 on IL-1Ra, since transient transfection with dominant-negative NF- B abolished IL-1 -induced IL-1Ra secretion. However, dominant-negative NF- B failed to modify the rosiglitazone-induced enhancement of IL-1Ra secretion in synoviocytes, which demonstrates that this pathway was not primarily involved despite its requirement for 
cellular activation. Based on previous studies on the human IL-1Ra promoter, one can suggest that rosiglita- zone could have affected alternate IL-1-sensitive trans- acting factors such as CCAAT/enhancer binding pro- teins or activator protein $1(60,61)$.

Second, we searched for the possible contribution of PPAR /, since high-dose rosiglitazone was shown to activate the PPAR-responsive promoter in cells express- ing PPAR / but not PPAR (19), whereas it inhibited inflammatory genes through activation of the PPAR / isotype in macrophages (62). This hypothesis was further supported by the inability of other PPAR (troglita- zone) and PPAR (Wy-14,643) agonists to affect IL-1 - induced IL-1Ra production. We demonstrated that PPAR / was expressed constitutively in synovial fibro- blasts, both at the mRNA and protein levels, and that its expression was not changed by cellular activation. In contrast, we showed that PPAR level decreased dra- matically in activated synoviocytes, thus confirming that this isotype was regulated negatively by inflammatory stimuli in articular cells (28). Such low levels of PPAR in inflammatory conditions would likely favor the bind- ing of rosiglitazone to PPAR / , despite its low affinity for this isotype (55). Consistent with a PPAR /-dependent mechanism, we demonstrated that induction of IL-1Ra secretion by rosiglitazone was abolished by transfection with a dominant-negative form of PPAR /. We showed further that a low concentration of GW-501516, a highly selective PPAR / agonist $(27,63,64)$, reproduced the stimulating effect of high- dose rosiglitazone on IL-1Ra secretion. Taken together, these data demonstrate that rosiglitazone enhanced IL-1Ra secretion in a PPAR / -dependent manner and that this likely occurred because its relative affinity for PPAR isotypes was counterbalanced by the pattern of expression of PPAR isotypes in response to IL-1 stimulation.

In conclusion, findings of the present study show that the PPAR agonists rosiglitazone and 15-deoxy- PGJ 2 had opposite effects on IL-1Ra production by IL-1 -stimulated rat synovial fibroblasts. Enhancement of IL-1Ra secretion by rosiglitazone tended to normalize the imbalance between IL-1 and IL-1Ra in activated cells, suggesting that it could contribute to the antiin- flammatory properties of this molecule in experimental polyarthritis. However, stimulation of IL-1Ra by rosiglitazone was supported neither by activation of PPAR nor by modulation of the NF- B pathway, but by activation of PPAR / . At dosages required to enhance IL-1Ra secretion in synovial fibroblasts, the cellular response to rosiglitazone was likely influenced by the pattern of expression of PPAR isotypes, which changed dramatically in response to IL-1 challenge. Although further studies are required to elucidate the molecular events that contribute to the control of IL-1Ra by PPAR / , our data suggest that activation of PPAR / may open new perspectives for the modulation of in- flammatory genes in articular cells.

\section{REFERENCES}

1. Dayer JM. The pivotal role of interleukin-1 in the clinical mani- festations of rheumatoid arthritis. Rheumatology (Oxford) 2003;42 Suppl 2:ii3-10.

2. Arend WP, Dayer JM. Cytokines and cytokine inhibitors or antagonists in rheumatoid arthritis. Arthritis Rheum 1990;33: 305-15.

3. Arend WP, Dayer JM. Inhibition of the production and effects of interleukin-1 and tumor necrosis factor in rheumatoid arthritis. Arthritis Rheum 1995;38:151-60.

4. Sweeney SE, Firestein GS. Rheumatoid arthritis: regulation of synovial inflammation. Int J Biochem Cell Biol 2004;36:372-8.

5. Breedveld FC, Emery P, Keystone E, Patel K, Furst DE, Kalden JR, et al. Infliximab in active early rheumatoid arthritis. Ann Rheum Dis 2004;63:149-55.

6. Bresnihan B, Cobby M. Clinical and radiological effects of anak- inra in patients with rheumatoid arthritis. Rheumatology (Oxford) 2003;42 Suppl 2:ii22-8.

7. Kary S, Burmester GR. Anakinra: the first interleukin-1 inhibitor in the treatment of rheumatoid arthritis. Int J Clin Pract 2003;57: $231-4$.

8. Dinarello CA. Biologic basis for interleukin-1 in disease. Blood 1996;87:2095-147.

9. Wesche H, Korherr C, Kracht M, Falk W, Resch K, Martin MU. The interleukin-1 receptor accessory protein (IL-1RAcP) is essen- tial for IL-1-induced activation of interleukin-1 receptor-associ- ated kinase (IRAK) and stress-activated protein kinases (SAP kinases). J Biol Chem 1997;272:7727-31.

10. Cullinan EB, Kwee L, Nunes P, Shuster DJ, Ju G, McIntyre KW, et al. IL-1 receptor accessory protein is an essential component of the IL-1 receptor. J Immunol 1998;161:5614-20.

11. Arend WP, Malyak M, Guthridge CJ, Gabay C. Interleukin-1 receptor antagonist: role in biology. Annu Rev Immunol 1998;16: 27-55.

12. Granowitz EV, Clark BD, Mancilla J, Dinarello CA. Interleukin-1 receptor antagonist competitively inhibits the binding of interleu- kin-1 to the type II interleukin-1 receptor. J Biol Chem 1991;266: 14147-50.

13. Firestein GS, Boyle DL, Yu C, Paine MM, Whisenand TD, Zvaifler NJ, et al. Synovial interleukin-1 receptor antagonist and interleukin-1 balance in rheumatoid arthritis. Arthritis Rheum 1994;37:644-52.

14. Gabay C, Marinova-Mutafchieva L, Williams RO, Gigley JP, Butler DM, Feldmann M, et al. Increased production of intracell- ular interleukin-1 receptor antagonist type $\mathrm{I}$ in the synovium of mice with collagen-induced arthritis: a possible role in the resolu- tion of arthritis. Arthritis Rheum 2001;44:451-62.

15. Fernandes J, Tardif G, Martel-Pelletier J, Lascau-Coman V, Dupuis M, Moldovan F, et al. In vivo transfer of interleukin-1 receptor antagonist gene in osteoarthritic rabbit knee joints: prevention of osteoarthritis progression. Am J Pathol 1999;154: $1159-69$.

16. Horai R, Saijo S, Tanioka H, Nakae S, Sudo K, Okahara A, et al. Development of chronic inflammatory arthropathy resembling rheumatoid arthritis in interleukin 1 receptor antagonist-deficient mice. J Exp Med 2000;191:313-20.

17. Desvergne B, Wahli W. Peroxisome proliferator-activated recep- tors: nuclear control of metabolism. Endocr Rev 1999;20:649-88.

18. Kliewer SA, Umesono K, Noonan DJ, Heyman RA, Evans RM. 
Convergence of 9-cis retinoic acid and peroxisome proliferator signalling pathways through heterodimer formation of their recep- tors. Nature 1992;358:771-4.

19. Ricote M, Li AC, Willson TM, Kelly CJ, Glass CK. The peroxi- some proliferator-activated receptor- is a negative regulator of macrophage activation. Nature 1998;391:79-82.

20. Jiang C, Ting AT, Seed B. PPAR- agonists inhibit production of monocyte inflammatory cytokines. Nature 1998;391:82-6.

21. Cuzzocrea S, Mazzon E, Dugo L, Patel NS, Serraino I, Di Paola R, et al. Reduction in the evolution of murine type II collagen-induced arthritis by treatment with rosiglitazone, a ligand of the peroxisome proliferator-activated receptor . Arthritis Rheum 2003;48:3544-56.

22. Cuzzocrea S, Pisano B, Dugo L, Ianaro A, Maffia P, Patel NS, et al. Rosiglitazone, a ligand of the peroxisome proliferator-activated receptor- , reduces acute inflammation. Eur J Pharmacol 2004; 483:79-93.

23. Saubermann LJ, Nakajima A, Wada K, Zhao S, Terauchi Y, Kadowaki T, et al. Peroxisome proliferator-activated receptor agonist ligands stimulate a Th2 cytokine response and prevent acute colitis. Inflamm Bowel Dis 2002;8:330-9.

24. Kawahito Y, Kondo M, Tsubouchi Y, Hashiramoto A, Bishop- Bailey D, Inoue K, et al. 15-deoxy- ${ }^{12,14}$-PGJ $_{2}$ induces synoviocyte apoptosis and suppresses adjuvant-induced arthritis in rats. J Clin Invest 2000;106:189-97.

25. Fahmi H, Di Battista JA, Pelletier JP, Mineau F, Ranger P, Martel-Pelletier J. Peroxisome proliferator-activated receptor activators inhibit interleukin-1 -induced nitric oxide and matrix metalloproteinase 13 production in human chondrocytes. Arthritis Rheum 2001;44:595-607.

26. Wahli W. Peroxisome proliferator-activated receptors (PPARs): from metabolic control to epidermal wound healing. Swiss Med Wkly 2002;132:83-91.

27. Oliver WR Jr, Shenk JL, Snaith MR, Russell CS, Plunket KD, Bodkin NL, et al. A selective peroxisome proliferator-activated receptor agonist promotes reverse cholesterol transport. Proc Natl Acad Sci U S A 2001;98:5306-11.

28. Simonin MA, Bordji K, Boyault S, Bianchi A, Gouze E, Becuwe P, et al. PPAR- ligands modulate effects of LPS in stimulated rat synovial fibroblasts. Am J Physiol Cell Physiol 2002;282:C125-33.

29. Meier CA, Chicheportiche R, Juge-Aubry CE, Dreyer MG, Dayer JM. Regulation of the interleukin-1 receptor antagonist in THP-1 cells by ligands of the peroxisome proliferator-activated receptor . Cytokine 2002;18:320-8.

30. Fujikawa Y, Shingu M, Torisu T, Masumi S. Interleukin-1 receptor antagonist production in cultured synovial cells from patients with rheumatoid arthritis and osteoarthritis. Ann Rheum Dis 1995;54:

$318-20$.

31. Liagre B, Vergne P, Rigaud M, Beneytout JL. Expression of arachidonate platelet-type 12-lipoxygenase in human rheumatoid arthritis type B synoviocytes. FEBS Lett 1997;414:159-64.

32. Gurnell M, Wentworth JM, Agostini M, Adams M, Collingwood TN, Provenzano C, et al. A dominant-negative peroxisome prolif- erator-activated receptor (PPAR ) mutant is a constitutive repressor and inhibits PPAR -mediated adipogenesis. J Biol Chem 2000;275:5754-9.

33. Bastie C, Luquet S, Holst D, Jehl-Pietri C, Grimaldi PA. Alter-ations of peroxisome proliferator-activated receptor activity affect fatty acidcontrolled adipose differentiation. J Biol Chem 2000;275:38768-73.

34. Gilroy DW, Colville-Nash PR, Willis D, Chivers J, Paul-Clark MJ, Willoughby DA. Inducible cyclooxygenase may have anti-inflammatory properties. Nat Med 1999;5:698-701.

35. Willoughby DA, Moore AR, Colville-Nash PR. Cyclopentenone prostaglandins-new allies in the war on inflammation. Nat Med 2000;6:137-8

36. Bordji K, Grillasca JP, Gouze JN, Magdalou J, Schohn H, Keller JM, et al. Evidence for the presence of peroxisome proliferator- activated receptor (PPAR) and and retinoid $\mathrm{Z}$ receptor in cartilage: PPAR activation modulates the effects of interleu-kin-1 on rat chondrocytes. J Biol Chem 2000;275:12243-50.

37. Fahmi H, Pelletier JP, Martel-Pelletier J. PPAR ligands as modulators of inflammatory and catabolic responses in arthritis: an overview. J Rheumatol 2002;29:3-14.

38. Sabatini M, Bardiot A, Lesur C, Moulharat N, Thomas M, Richard I, et al. Effects of agonists of peroxisome proliferator-activated receptor on proteoglycan degradation and matrix metallopro- teinase production in rat cartilage in vitro. Osteoarthritis Cartilage 2002;10:673-9.

39. Fahmi H, Pelletier JP, Di Battista JA, Cheung HS, Fernandes JC, Martel-Pelletier J. Peroxisome proliferator-activated receptor activators inhibit MMP-1 production in human synovial fibroblasts likely by reducing the binding of the activator protein 1. Osteoar- thritis Cartilage 2002;10:100-8.

40. Lacey D, Sampey A, Mitchell R, Bucala R, Santos L, Leech M, et al. Control of fibroblast-like synoviocyte proliferation by macro- phage migration inhibitory factor. Arthritis Rheum 2003;48:103-9.

41. Seemayer CA, Kuchen S, Kuenzler P, Rihoskova V, Rethage J, Aicher WK, et al. Cartilage destruction mediated by synovial fibroblasts does not depend on proliferation in rheumatoid arthri- tis. Am J Pathol 2003;162:1549-57.

42. Smeets TJ, Barg EC, Kraan MC, Smith MD, Breedveld FC, Tak PP. Analysis of the cell infiltrate and expression of proinflamma- tory cytokines and matrix metalloproteinases in arthroscopic syno- vial biopsies: comparison with synovial samples from patients with end stage, destructive rheumatoid arthritis. Ann Rheum Dis 2003;62:635-8.

43. Martel-Pelletier J, McCollum R, Pelletier JP. The synthesis of IL-1 receptor antagonist (IL-1ra) by synovial fibroblasts is markedly increased by the cytokines TNF and IL-1. Biochim Biophys Acta 1993;1175:302-5.

44. Palmer G, Mezin F, Juge-Aubry CE, Plater-Zyberk C, Gabay C, Guerne PA. Interferon stimulates interleukin 1 receptor antag- onist production in human articular chondrocytes and synovial fibroblasts. Ann Rheum Dis 2004;63:43-9.

45. Marsh CB, Wewers MD. Cytokine-induced interleukin-1 receptor antagonist release in mononuclear phagocytes. Am J Respir Cell Mol Biol 1994;10:521-5.

46. Rupp J, Kothe H, Mueller A, Maass M, Dalhoff K. Imbalanced secretion of IL-1 and IL-1RA in Chlamydia pneumoniae-infected mononuclear cells from COPD patients. Eur Respir J 2003;22: 274-9.

47. Ward JE, Gould H, Harris T, Bonacci JV, Stewart AG. PPAR ligands, 15-deoxy- ${ }^{12,14}$-prostaglandin $\mathrm{J}_{2}$ and rosiglitazone regu- late human cultured airway smooth muscle proliferation through different mechanisms. Br J Pharmacol 2004;141:517-25.

48. Keelan J, Helliwell R, Nijmeijer B, Berry E, Sato T, Marvin K, et al. 15-deoxy- ${ }^{12,14}$-prostaglandin $\mathrm{J}_{2}$-induced apoptosis in amnion- like WISH cells. Prostaglandins Other Lipid Mediat 2001;66: $265-82$.

49. Boyault S, Simonin MA, Bianchi A, Compe E, Liagre B, Mainard D, et al. 15-deoxy- ${ }^{12,14}$ PGJ $_{2}$, but not troglitazone, modulates IL-1 effects in human chondrocytes by inhibiting NF- B and AP-1 activation pathways. FEBS Lett 2001;501:24-30.

50. Takeda K, Ichiki T, Tokunou T, Funakoshi Y, lino N, Hirano K, et al. Peroxisome proliferator-activated receptor activators downregulate angiotensin II type 1 receptor in vascular smooth muscle cells. Circulation 2000;102:1834-9.

51. Sugawara A, Takeuchi K, Uruno A, Ikeda Y, Arima S, Kudo M, et al. Transcriptional suppression of type 1 angiotensin II receptor gene expression by peroxisome proliferator-activated receptor- in vascular smooth muscle cells. Endocrinology 2001;142:3125-34.

52. Hayes MM, Lane BR, King SR, Markovitz DM, Coffey MJ. Peroxisome proliferator-activated receptor agonists inhibit HIV-1 replication in macrophages by transcriptional and post- transcriptional effects. J Biol Chem 2002;277:16913-9. 
53. Nosjean O, Boutin JA. Natural ligands of PPAR : are prostaglan- din $\mathrm{J}_{2}$ derivatives really playing the part? Cell Signal 2002;14: 573-83.

54. Li L, Tao J, Davaille J, Feral C, Mallat A, Rieusset J, et al.

15-deoxy- ${ }^{12,14}$-prostaglandin $\mathrm{J}_{2}$ induces apoptosis of human he- patic myofibroblasts: a pathway involving oxidative stress indepen- dently of peroxisome-proliferator-activated receptors. J Biol Chem 2001;276:38152-8.

55. Willson TM, Brown PJ, Sternbach DD, Henke BR. The PPARs: from orphan receptors to drug discovery. J Med Chem 2000;43: 527-50.

56. Singh Ahuja H, Liu S, Crombie DL, Boehm M, Leibowitz MD, Heyman RA, et al. Differential effects of rexinoids and thiazo- lidinediones on metabolic gene expression in diabetic rodents. Mol Pharmacol 2001;59:765-73.

57. Tailleux A, Torpier G, Mezdour H, Fruchart JC, Staels B, Fievet C. Murine models to investigate pharmacological compounds acting as ligands of PPARs in dyslipidemia and atherosclerosis. Trends Pharmacol Sci 2003;24:530-4.

58. Crofford LJ, Tan B, McCarthy CJ, Hla T. Involvement of nuclear factor B in the regulation of cyclooxygenase-2 expression by interleukin-1 in rheumatoid synoviocytes. Arthritis Rheum 1997; 40:226-36.

59. Carter AB, Tephly LA, Hunninghake GW. The absence of acti- vator protein 1-dependent gene expression in THP-1 macrophages stimulated with phorbol esters is due to lack of p38 mitogen-activated protein kinase activation. J Biol Chem 2001;276: 33826-32.

60. Gabay C, Smith MF, Eidlen D, Arend WP. Interleukin 1 receptor antagonist (IL-1Ra) is an acute-phase protein. J Clin Invest 1997;99:2930-40

61. Jenkins JK, Drong RF, Shuck ME, Bienkowski MJ, Slightom JL, Arend WP, et al. Intracellular IL-1 receptor antagonist promoter: cell type-specific and inducible regulatory regions. J Immunol 1997;158:748-55

62. Welch JS, Ricote M, Akiyama TE, Gonzalez FJ, Glass CK

PPAR and PPAR negatively regulate specific subsets of lipo-polysaccharide and IFN target genes in macrophages. Proc Natl Acad Sci U S A 2003;100:6712-7.

63. Sznaidman ML, Haffner CD, Maloney PR, Fivush A, Chao E, Goreham D, et al. Novel selective small molecule agonists for peroxisome proliferator-activated receptor (PPAR ): synthesis and biological activity. Bioorg Med Chem Lett 2003;13:1517-21.

64. Stephen RL, Gustafsson MC, Jarvis M, Tatoud R, Marshall BR, Knight D, et al. Activation of peroxisome proliferator-activated receptor stimulates the proliferation of human breast and prostate cancer cell lines. Cancer Res 2004;64:3162-70.

Figure 1. Modulation of interleukin-1 receptor antagonist (IL-1Ra) expression by peroxisome proliferator-activated receptor agonists in rat synovial fibroblasts. Synoviocytes were incubated with $10 \mathrm{M}$

15-deoxy- ${ }^{12,14}$-prostaglandin $\mathrm{J}_{2}\left(15 \mathrm{~d}-\mathrm{PGJ}_{2}\right), 10 \quad M$ rosiglitazone

(Rosi), or $0.1 \%$ DMSO in the presence or absence of $10 \mathrm{ng} / \mathrm{ml}$ of

IL-1. A, Messenger RNA levels at 12 hours, as demonstrated by real-time polymerase chain reaction analysis of total RNA. Data represent the ratio of IL-1Ra mRNA to S29 mRNA and are expressed as the percentage relative arbitrary units, where control represents

$100 \%$. B, Protein secreted into culture supernatants at 24 hours, as measured by enzyme-linked immunosorbent assay. Values are the mean SD (n 3 experiments). $\quad P \quad 0.05$ versus control; \# $P$

0.05 versus IL-1 treatment.

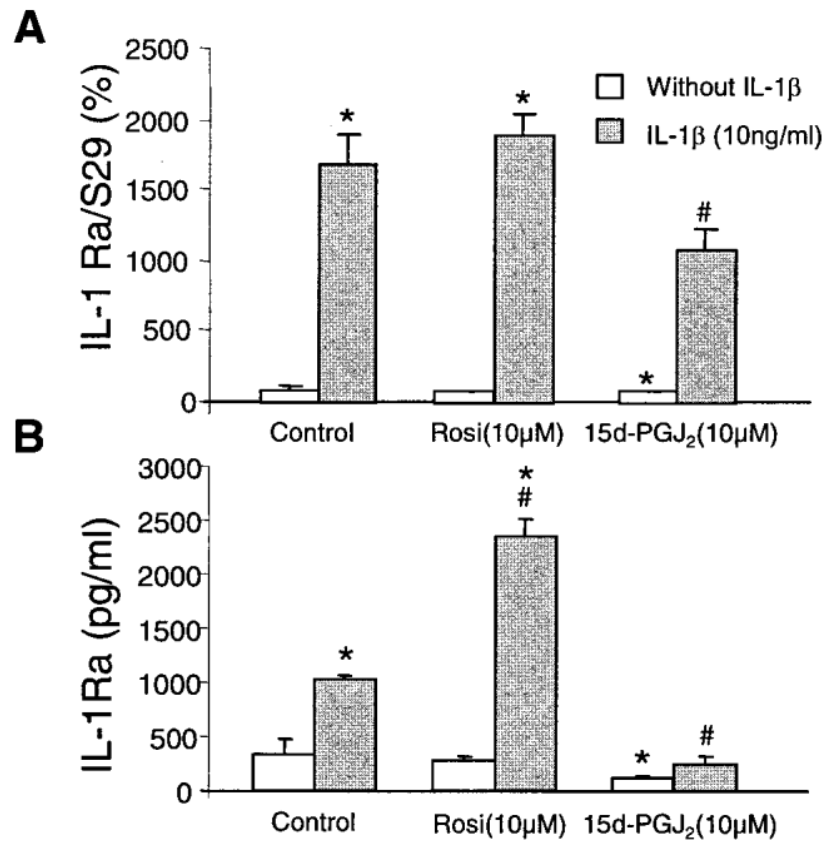



Table 1. Secretion of IL-1 and IL-1Ra by IL-1 -stimulated synoviocytes*

\begin{tabular}{|c|c|}
\hline $\begin{array}{c}\text { IL-1 secretion, } \\
\mathrm{pg} / \mathrm{ml}\end{array}$ & $\begin{array}{c}\text { IL-1Ra secretion, } \\
\mathrm{pg} / \mathrm{ml}\end{array}$ \\
\hline
\end{tabular}




\begin{tabular}{|c|c|c|c|c|c|}
\hline Control & & 5 & & $\begin{array}{ll}38 & 12\end{array}$ & 0.14 \\
\hline IL-1 , 10 mg/ml & 237 & $18 \dagger$ & & $24964 \dagger$ & 0.95 \\
\hline $\begin{array}{c}\text { Rosiglitazone, } 10 M \\
\text { Alone }\end{array}$ & & & 5 & 3215 & \\
\hline Plus IL-1 & & $\begin{array}{r}0.16 \\
128 \\
0.41\end{array}$ & $23 \dagger t$ & $30990 \dagger$ & \\
\hline $\begin{array}{c}\text { 15-deoxy-PGJ } \\
\text { Alone }\end{array}$ & & 0.28 & 5 & $185 \dagger$ & \\
\hline Plus IL-1 & & 137 & $7+t$ & $11364 \dagger$ & \\
\hline
\end{tabular}

* Values are the mean SD of 3 experiments. IL-1 interleukin-1 ; IL-1Ra interleukin-1 receptor antagonist; 15 -deoxy-PGJ 2 15-deoxy- ${ }^{12,14}$-prostaglandin $\mathrm{J}_{2}$.

$\dagger P 0.05$ versus control.

$₫ P \quad 0.05$ versus IL-1 treatment.

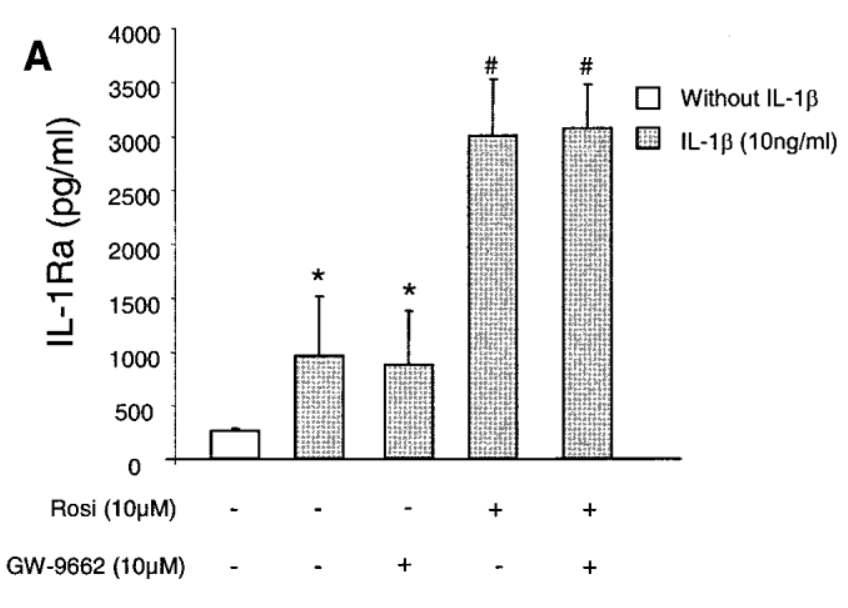

\section{B}
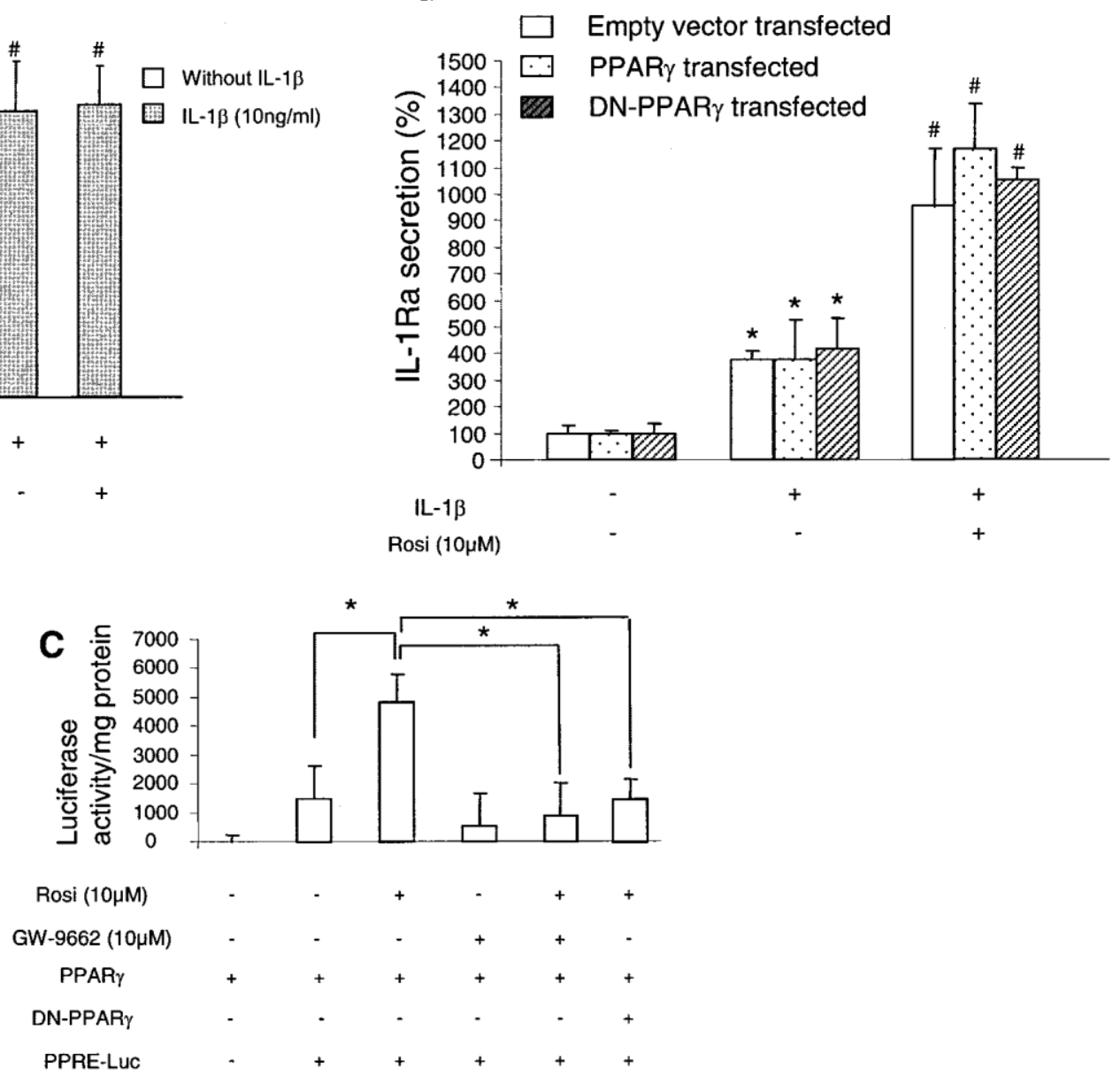

Figure 2. Effects of peroxisome proliferator-activated receptor (PPAR ) modulation on rosiglitazone (Rosi)-induced interleukin-1 receptor antagonist (IL-1Ra) secretion by synovial fibroblasts. A, Effect of the PPAR -specific antagonist GW-9662 on IL-1Ra secretion into culture supernatants, as measured by enzyme-linked immunosorbent assay (ELISA). Cells were stimulated for 24 hours with $10 \mathrm{ng} / \mathrm{ml}$ of IL-1 in the presence or absence of $10 M$ PPAR ligands. \# $P$ P 0.05 versus IL-1 treatment. B, Effect of PPAR wild-type and dominant-negative (DN) transfection on rosiglitazone-induced IL-1Ra secretion by synovial fibroblasts. Transfected cells were stimulated for 24 hours with $10 \mathrm{ng} / \mathrm{ml}$ of IL-1 in the presence or absence of $10 \mathrm{M}$ rosiglitazone. Data represent the level of IL-1Ra secretion into culture supernatants, as measured by ELISA. $\quad P \quad 0.05$ versus control; \# $P \quad 0.05$ versus IL-1 treatment. C, Peroxisome proliferator-activated receptor response element (PPRE) luciferase (Luc) activity in cells exposed to rosiglitazone. $\quad P \quad 0.05$. Values are the mean $\mathrm{SD}(\mathrm{n} \quad 3$ experiments in $\mathbf{A}$ and $\mathbf{B} ; \mathrm{n} \quad 6$ 


\section{Empty vector transfected}

A

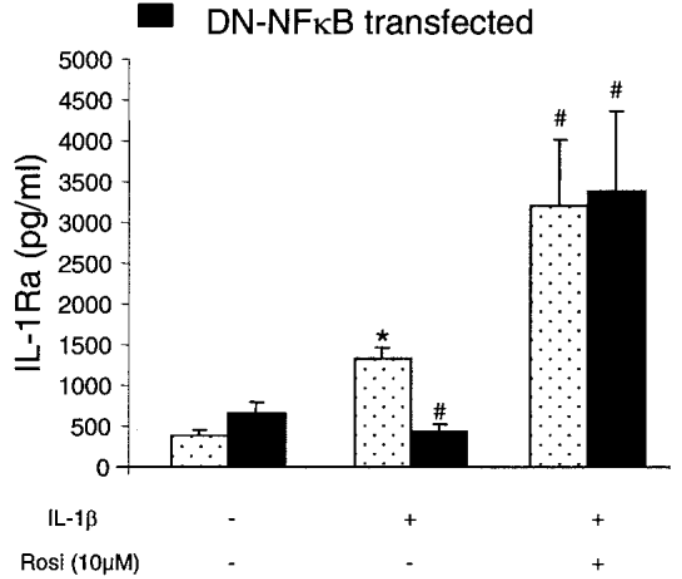

B

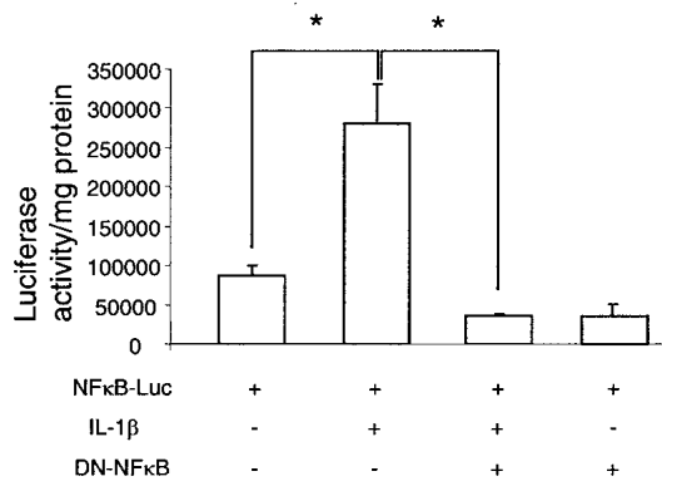

Figure 3. Effects of NF- B inhibition on rosiglitazone-induced interleukin-1 receptor antagonist (IL-1Ra) secretion by synovial fibroblasts. Cells were stimulated for 24 hours with $10 \mathrm{ng} / \mathrm{ml}$ of interleukin-1 (IL-1) in the presence or absence of $10 \quad M$ rosiglitazone (Rosi). A, Effect of dominant-negative (DN) NF- B on IL-1Ra secretion into culture supernatants, as measured by enzyme-linked immunosorbent assay. $\quad P \quad 0.05$ versus control; \# $P \quad 0.05$ versus IL-1 treatment. B, NF- B luciferase (Luc) activity in cells exposed to IL-1 . $\quad P \quad 0.05$. Values are the mean SD (n 3 experiments in $\mathbf{A} ; \mathrm{n} 6$ experiments in $\mathbf{B})$.

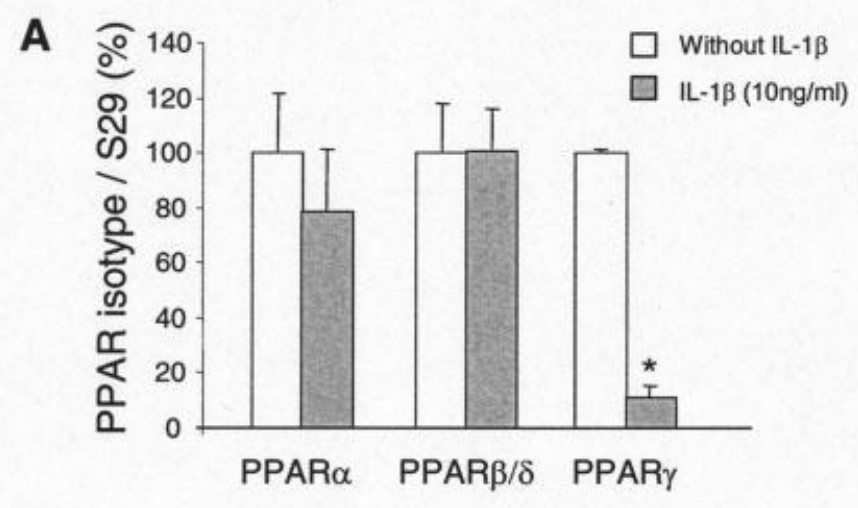

B
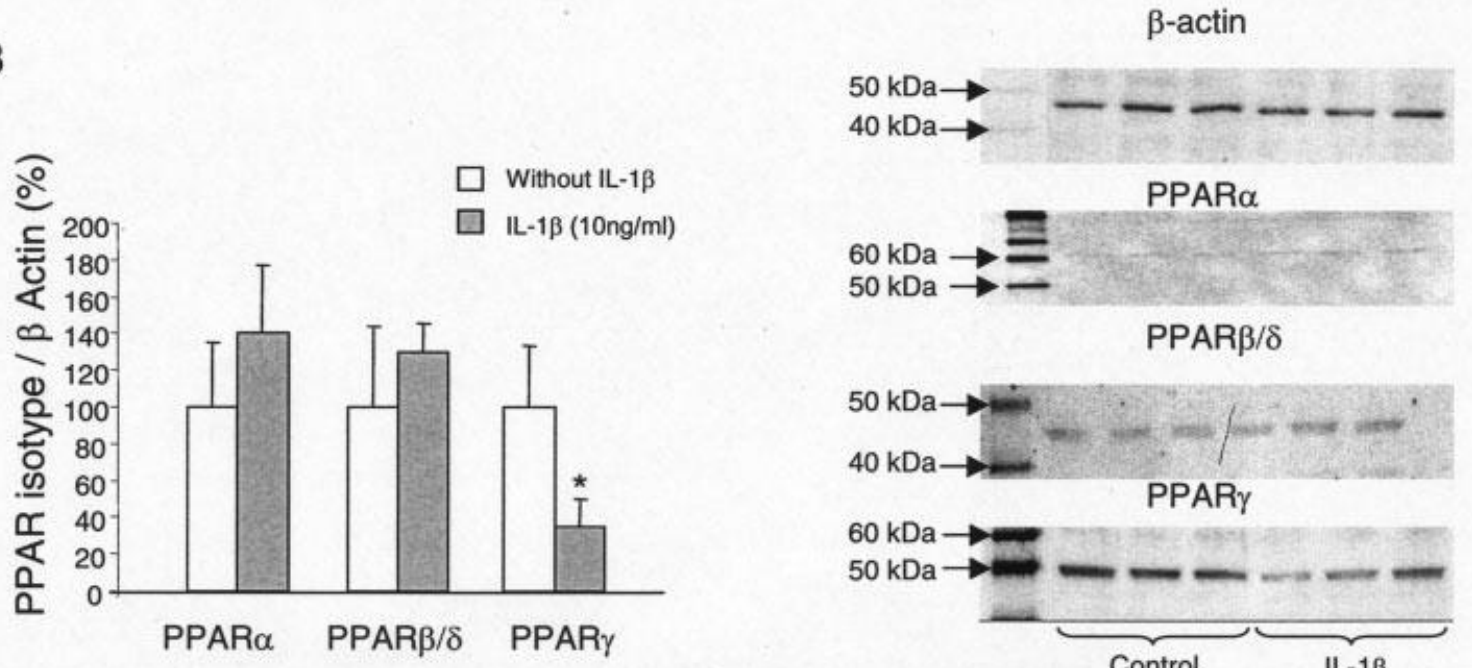

PPAR $\beta / \delta$

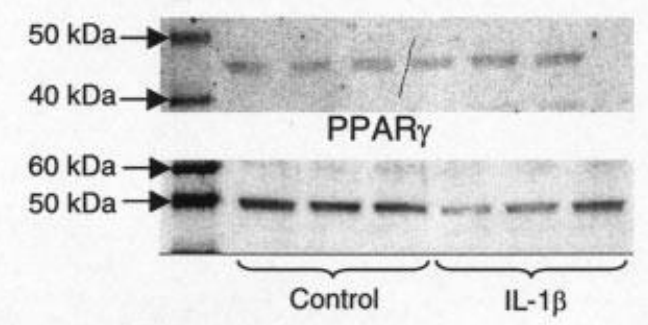

Figure 4. Effects of interleukin-1 (IL-1; $10 \mathrm{ng} / \mathrm{ml}$ ) on the expression of peroxisome proliferator-activated receptor (PPAR) isotypes in rat synovial fibroblasts. A, Messenger RNA level at 6 hours (shown as the results of real-time polymerase chain reaction of total RNA). Data represent the ratio of PPAR mRNA to S29 mRNA and are expressed as the percentage relative arbitrary units, where control represents $100 \% . \quad P \quad 0.05$ versus control. B, Protein level at 12 hours, as determined by Western blot analysis. Data represent the ratio of PPAR protein to -actin protein and are expressed as relative arbitrary units, where control represents $100 \% . \quad P \quad 0.05$. Controls experiments using resting cells were performed for each experiment. Values are the mean SD (n 3 experiments). 


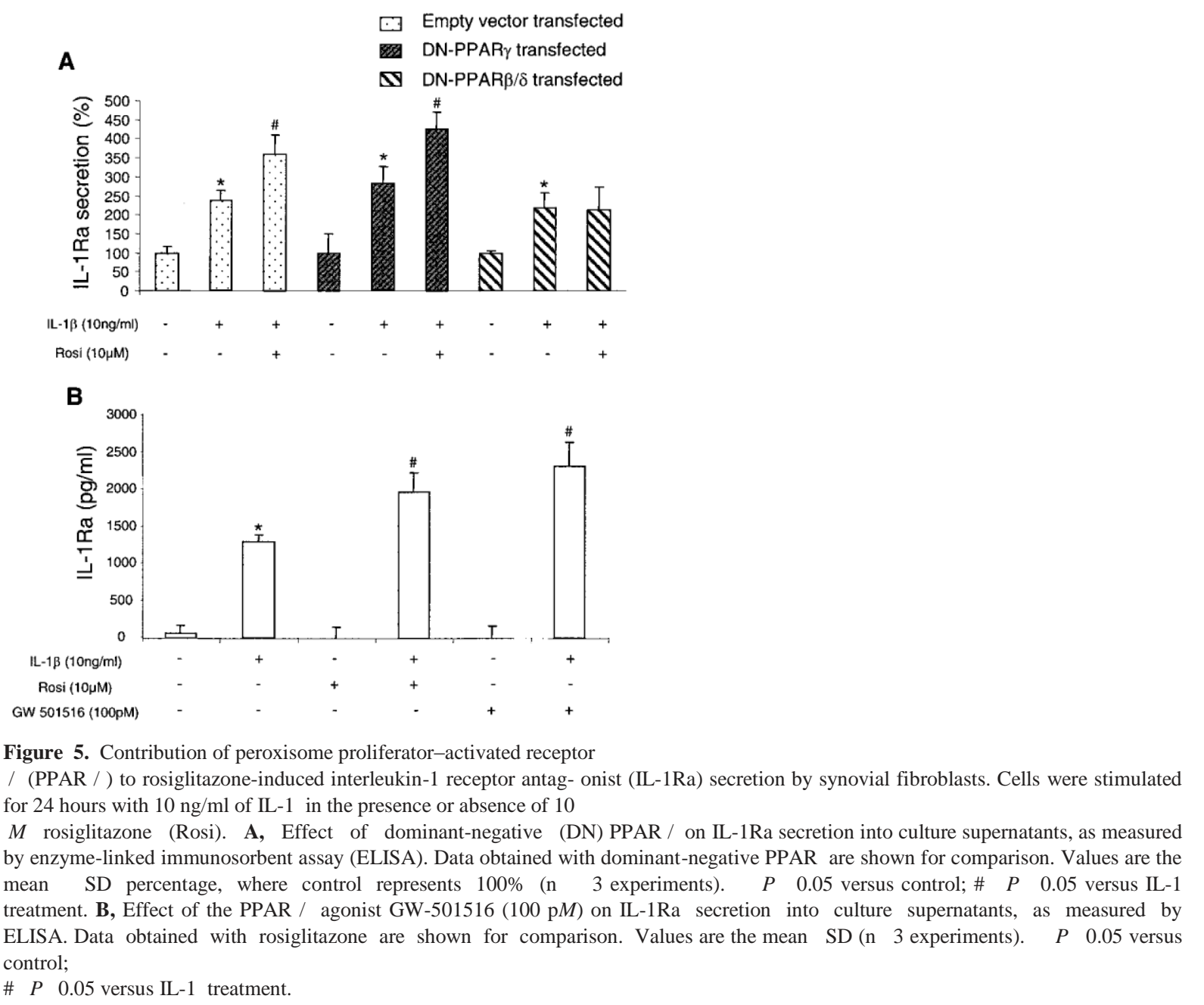

